\title{
Evaluation of alcaftadine $0.25 \%$ ophthalmic solution in acute allergic conjunctivitis at 15 minutes and 16 hours after instillation versus placebo and olopatadine $0.1 \%$
}

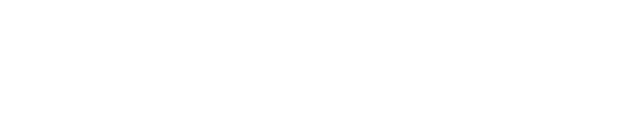

Jack V Greiner ${ }^{1,2}$

Kimberly Edwards-

Swanson ${ }^{3}$

Avner Ingerman ${ }^{4}$

'Schepens Eye Research Institute, Boston, MA; ${ }^{2}$ Department of Ophthalmology, Harvard Medical School, Boston, MA; J Johnson \& Johnson Consumer and Personal Products Worldwide, Skillman, NJ; ${ }^{4}$ Ora Inc, Andover, MA, USA
Correspondence: Jack V Greiner Schepens Eye Research Institute Boston, MA, USA

Tel (78I) 7293008

Fax (78I) 7292402

Email jackvgreiner@msn.com
Purpose: To evaluate the effectiveness of alcaftadine $0.05 \%, 0.1 \%$, and $0.25 \%$ ophthalmic solutions in treating the signs and symptoms of allergic conjunctivitis when compared with olopatadine hydrochloride $0.1 \%$ and placebo using the conjunctival allergen challenge (CAC) model.

Methods: One hundred and seventy subjects were randomized and 164 subjects completed all visits. CAC was performed to determine and confirm subjects' eligibility at visits 1 and 2, respectively. The CAC was repeated at visit 3 (day $0 \pm 3$ ), 16 hours after study medication instillation, and at visit 4 (day $14 \pm 3$ ), 15 minutes after instillation. Ocular itching and conjunctival redness were evaluated after an allergen challenge, along with several secondary endpoints.

Results: Alcaftadine $0.25 \%$ and olopatadine $0.1 \%$ treatments exhibited significantly lower mean scores compared with placebo for ocular itching and conjunctival redness at visits 3 and 4 . Most adverse events were self-limiting and mild in severity. No serious treatment-related adverse events occurred.

Conclusion: Treatment with alcaftadine $0.25 \%$ ophthalmic solution resulted in mean differences of $>1$ unit (ocular itching) and approximately $>1$ unit (conjunctival redness), which was significant $(P<0.001)$ compared with placebo treatment. All doses of alcaftadine were safe and well tolerated in the population studied.

Keywords: alcaftadine, allergic conjunctivitis, conjunctival allergen challenge

\section{Introduction}

Allergic conjunctivitis is an inflammatory condition that can be triggered by a variety of stimuli, including tree and grass pollens, animal hair or dander, and other environmental allergens. The most common and distressing ocular signs and symptoms associated with allergic conjunctivitis are redness (hyperemia) and itching (pruritus), respectively; other frequent signs include eyelid swelling (edema), swelling of the conjunctiva (chemosis), and tearing. ${ }^{1}$ The physiologic basis for allergies is multifactorial and involves both an early acute phase triggered by mast cell degranulation and release of histamine and a late phase involving various proinflammatory mediators including prostaglandins, leukotrienes, cytokines, and interleukins. ${ }^{2}$ The activation of $\mathrm{H}_{1}$ receptors found on conjunctival neurons by histamine released from mast cells is the cause of itching. ${ }^{3}$ Histamine binding to $\mathrm{H}_{1}$ and $\mathrm{H}_{2}$ receptors on the vascular endothelium induces dilation (seen as redness) and endothelial swelling. ${ }^{1,4} \mathrm{H}_{4}$ receptors widely expressed on immune and inflammatory cells also play a role in itching and inflammation. ${ }^{5-7}$ 
Allergies are relatively common among the general population, affecting more than $15 \%$ of the global population and up to $30 \%$ of the US population, and the prevalence is increasing, probably due to environmental factors (pollution, pollen, air conditioning). ${ }^{1}$

Current treatments for allergic conjunctivitis include a variety of therapies from different classes of drugs, including antihistamine-vasoconstrictor combinations, antihistamine-mast cell stabilizers, corticosteroids, nonsteroidal anti-inflammatory drugs, antihistamines, and antihistamine-mast cell stabilizer combinations. Dualfunction agents (antihistamine, mast cell stabilization) have become the mainstay of pharmacologic therapy for ocular allergic disease; these therapies vary in potency, specificity, and duration of action, as demonstrated in varied dosing regimens. ${ }^{1}$

Alcaftadine (11-[1-methylpiperidin-4-ylidene]-6, 11-dihydro-5H-imidazo [2, 1-b] [3] benzazepine-3carbaldehyde) is a new chemical entity developed as an antiallergic agent. Alcaftadine is a potent histamine $\mathrm{H}_{1}$, $\mathrm{H}_{2}$, and $\mathrm{H}_{4}$ receptor antagonist that has also demonstrated anti-inflammatory properties (unpublished data on file at Vistakon Pharmaceuticals, LLC, Jacksonville, FL, USA). Phase I safety studies of topically applied alcaftadine ophthalmic solutions have been completed and indicate that alcaftadine concentrations in the range of $0.05 \%$ to $0.25 \%$ are safe, well tolerated, and warrant further investigation for efficacy. Furthermore, alcaftadine has demonstrated protective characteristics relative to the induction phase of allergy; preclinical studies have shown it stabilized tight junction protein (zonula occludin-1) expressed in the conjunctival epithelium that normally becomes disorganized following allergen exposure (unpublished data on file at Vistakon Pharmaceuticals, LLC). In preclinical studies, the effects exhibited by alcaftadine, including a reduction in itching, redness, and eosinophil recruitment, accurately reflect the expected pharmacologic profile of a broad-spectrum antihistamine. ${ }^{1,4,5}$

This report describes the first clinical evaluation of the effectiveness of alcaftadine ophthalmic solution in treating the signs and symptoms of allergic conjunctivitis. Three concentrations of alcaftadine ophthalmic solution $(0.05 \%$, $0.1 \%$, and $0.25 \%$ ) were compared with the vehicle of the alcaftadine ophthalmic solutions as a placebo control and with an active control (olopatadine hydrochloride ophthalmic solution, $0.1 \%$ ) for effectiveness in alleviating the signs and symptoms of allergic conjunctivitis using the conjunctival allergen challenge (CAC) model. ${ }^{2,8}$

\section{Materials and methods Study design}

This was a prospective, single-center, double-masked, randomized, active- and placebo-controlled CAC study. The study comprised four visits over a period of five weeks. The study was approved by an independent review board (IntegReview, Austin, TX, USA), and all procedures followed the tenets of the Declaration of Helsinki and were consistent with Good Clinical Practices and applicable regulatory requirements. All subjects signed an independent review board-approved, written informed consent and Health Insurance Portability and Accountability Act form before commencement of the study procedures.

Inclusion and exclusion criteria included the following: subjects had to be at least 18 years of age; if female, have a negative pregnancy test at visit 1 and upon exit from the study; have a positive history of ocular allergies and/or a positive skin test reaction to specified allergens within the last 24 months; have a best-corrected visual acuity of 0.6 $\log$ MAR or better in each eye, as measured using an Early Treatment Diabetic Retinopathy Study chart; and no wearing of contact lenses for at least three days prior to and during the study period. Subjects could not have any ocular or systemic condition that, in the opinion of the investigator, could affect the subject's safety or trial parameters; manifest signs or symptoms of clinically active allergic conjunctivitis in either eye at the start of any visit; have undergone ocular surgical intervention within three months; have had a history of refractive surgery within six months; have used aspirin, aspirin-containing products, or $\mathrm{H}_{1}$-antagonist antihistamines within 72 hours; immunotherapeutic agents unless treatment had been maintained steadily for at least two months; corticosteroids or mast cell stabilizers within 14 days, any other topical ophthalmic preparations (including tear substitutes) other than the study drops within 72 hours; or an investigational drug or device within 30 days of the study; or to have been enrolled in another investigational drug or device study within 30 days.

Visits 1 and 2 were screening visits during which the CAC was conducted and subjects' eligibility was assessed. At visit 1 (day -21), the allergen dose was titrated; a positive response was defined as a score of $\geq 2$ on a $0-4$ scale for both ocular itching and redness in at least two of the three vessel beds (conjunctival, episcleral, ciliary) at 10 minutes after an allergen challenge. Subjects were required to have a positive bilateral CAC reaction for at least two of the three time points for inclusion in the study. At visit 2 (day $-14 \pm 3$ ), the $\mathrm{CAC}$ was repeated; eligibility criteria included a score of 
$\geq 2$ for ocular itching, and a mean value of $\geq 2$ for redness at 10 minutes after an allergen challenge to confirm the reproducibility of the allergic response.

At visit 3, eligible subjects were randomly assigned to one of the five treatment groups, ie, placebo, alcaftadine $0.05 \%$, $0.1 \%$, or $0.25 \%$, or active control (olopatadine hydrochloride ophthalmic solution, $0.1 \%$, Alcon Laboratories Inc, Fort Worth, TX, USA). It should be noted that the alcaftadine $0.25 \%$ ophthalmic solution tested in this study was not the final commercial formulation.

Sixteen hours following study medication instillation at visit 3 (day $0 \pm 3$ ), a CAC was performed to assess duration of action. At visit 4 (day $14 \pm 3$ ), the CAC was repeated 15 minutes after study medication instillation to assess onset of action.

The primary endpoints were ocular itching (at visit 4, five minutes after an allergen challenge) and conjunctival redness (at visit 4, 15 minutes after a challenge). Itching was evaluated by the subject for each eye at minutes 3,5, and 7 after a challenge at visits 3 and 4 . Ratings were made on a scale of 0 (none) to 4 (severe), allowing half-unit increments. Conjunctival redness was evaluated by the investigator for each eye at minutes 7,15 , and 20 after a challenge on the same scale. Secondary endpoints, assessed at minutes 7, 15, and 20 after a challenge, included ciliary and episcleral redness, chemosis, lid swelling, tearing, ocular mucous discharge, and nasal symptoms (sneezing, rhinorrhea, nasal congestion, nasal pruritus, and ear or palate pruritus). Nasal symptom composite scores were also calculated.

All adverse events, regardless of relationship to the study drug, were monitored and reported throughout the study. Adverse events were defined in the protocol and included any unfavorable or unintended sign or symptom observed by the physician or reported by the subject. In addition, standard ophthalmic examinations, $\log$ MAR visual acuity, and undilated funduscopy examinations were conducted as safety evaluations.

\section{Statistical methods}

All efficacy analyses were performed on the intent-to-treat population, including all randomized subjects. Safety analyses were performed on the safety population, including all randomized subjects who received study medication. The average scores from bilateral eyes for both ocular itching at the 5-minute postchallenge time point at visit 4 and conjunctival redness at the 15-minute postchallenge time point at visit 4 were analyzed using a nonparametric Wilcoxon rank sum test. A particular dose level compared with placebo was considered statistically significant if both primary endpoints were significant at the $\alpha$ (two-sided) $1.7 \%$ level. All statistical comparisons for secondary efficacy endpoints were made at the $\alpha$ (two-sided) 5\% level. The dose-response relationship was assessed using Spearman rank correlation and analyses of covariance for the primary variables at the corresponding visit and time point. For all tests, the average score of both eyes was used as the primary response variable.

Adverse events were coded by body system and preferred terms using the MedDRA Dictionary (Version 7.0). The number and percentage of subjects reporting any adverse events during the entire study were summarized for the three dose levels of alcaftadine and for placebo and olopatadine. The number and percentage of subjects reporting adverse events were also summarized by relationship to the study drug, as well as severity.

\section{Results}

The intent-to-treat population for this study consisted of all individuals who met the response criteria at visit 2 described in the methods. Of the 170 subjects included following this visit, the mean score for ocular itching (five minutes after CAC) was 2.76; the mean values for each of the five treatment groups were $2.71,2.74,2.82,2.72$, and 2.82. Scores exhibited a similar distribution for the redness measures at visit 2, and, as with the itching scores, there were no significant differences between scores for any of the groups established by randomization following visit 2 . This result shows that the random distribution of subjects created five treatment groups with comparable allergic signs and symptoms as measured in the CAC model. Each of the groups (placebo, alcaftadine $0.05 \%$, alcaftadine $0.1 \%$, alcaftadine $0.25 \%$, olopatadine $0.1 \%$ ) were randomly assigned 34 subjects, and of the 170 individuals in this intent-to-treat population, 164 subjects $(96.5 \%)$ completed the study and six subjects (3.5\%) discontinued. In general, the five treatment groups were evenly balanced with regard to demographics and baseline characteristics (Table 1).

\section{CAC at 15 minutes after instillation of medication (onset of action)}

All active treatment groups were clinically ( $\geq 1$ unit difference) and statistically $(P<0.001)$ superior to placebo at all time points for prevention of ocular itching (Figure 1, Table 2). Mean differences from placebo for alcaftadine $0.25 \%$ were $-1.95,-1.92$, and -1.77 units at $3-, 5-$, and 7-minute post-CAC time points, respectively, whereas those for olopatadine were $-1.89,-1.84$, and -1.66 , respectively (Table 2). 
Table I Demographics

\begin{tabular}{|c|c|c|c|c|c|c|}
\hline & Placebo* & $\begin{array}{l}\text { Alcaftadine } \\
0.05 \%\end{array}$ & $\begin{array}{l}\text { Alcaftadine } \\
0.1 \%\end{array}$ & $\begin{array}{l}\text { Alcaftadine } \\
0.25 \%\end{array}$ & $\begin{array}{l}\text { Olopatadine } \\
0.1 \%\end{array}$ & Total \\
\hline $\mathrm{N}$ & 34 & 34 & 34 & 34 & 34 & 170 \\
\hline Age, mean (SD) & $38.9(9.9)$ & 44.7 (II.5) & $44.5(9.5)$ & $4 I .0(14.1)$ & $38.5(11.2)$ & $4 I .5$ (II.5) \\
\hline \multicolumn{7}{|l|}{ Gender, N } \\
\hline Male (\%) & I3 (38.2) & $9(26.5)$ & I5 (44.I) & I3 (38.2) & I5 (44.I) & 65 (38.2) \\
\hline Female (\%) & $21(61.8)$ & $25(73.5)$ & $19(55.9)$ & $21(61.8)$ & $19(55.9)$ & $105(6 \mid .8)$ \\
\hline \multicolumn{7}{|l|}{ Race, N } \\
\hline Asian (\%) & 0 & 0 & 0 & I (2.9) & I (2.9) & $2(1.2)$ \\
\hline Black (\%) & 0 & $2(5.9)$ & I (2.9) & 0 & $2(5.9)$ & $5(2.9)$ \\
\hline Caucasian (\%) & $33(97.1)$ & 31 (9I.2) & $32(94.1)$ & $32(94.1)$ & $30(88.2)$ & 158 (92.9) \\
\hline Other & I (2.9) & I (2.9) & I (2.9) & I (2.9) & I (2.9) & $5(2.9)$ \\
\hline
\end{tabular}

Note: "Placebo refers to the use of the vehicle of the alcaftadine ophthalmic solutions as placebo control.

The mean conjunctival redness scores for all active treatment groups were lower than those of the placebo group at every postchallenge time point (Figure 2, Table 3). All concentrations of alcaftadine, as well as olopatadine, were statistically significantly different as compared with placebo in preventing redness at the first post-CAC evaluation ( 7 minutes), as were the alcaftadine $0.25 \%$ and olopatadine treatment groups at the 15- and 20-minute postchallenge time points. The difference in mean scores for olopatadine and alcaftadine $0.25 \%$ achieved clinical significance $(\geq 1$ unit difference) compared with placebo at one postchallenge time point ( 7 minutes), with -1.27 and -1.35 unit differences, respectively.

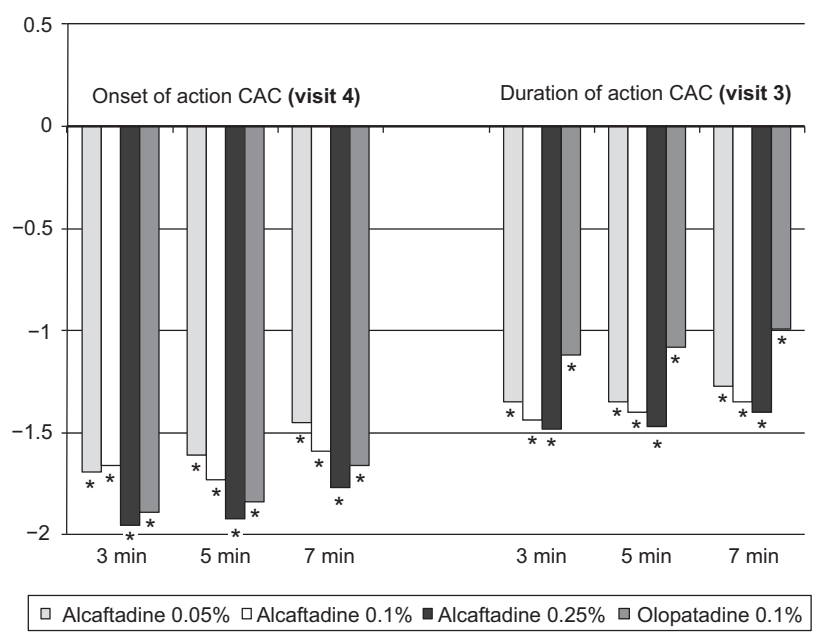

Figure I Ocular itching scores at 3, 5, and 7 minutes postchallenge. Plots show the mean difference for each treatment group (treatment score - placebo score). Note: *Statistically significant difference from placebo $(P<0.05)$. On the left, data for onset of action, CAC 15 minutes after instillation. On the right, data for duration of action, CAC 16 hours after instillation.

Abbreviation: CAC, conjunctival allergen challenge.

\section{CAC 16 hours after instillation of medication (duration of action)}

At the 16-hour post-CAC evaluation, all three alcaftadine concentrations produced lower mean ocular itching scores than both placebo and olopatadine (Figure 1, Table 2). All active treatment groups had clinically and statistically significantly lower scores than placebo at all time points, with the exception of clinical significance for olopatadine at 7 minutes postchallenge. At 7 minutes, the difference in the prevention of itching was statistically significant for alcaftadine $0.25 \%$ versus olopatadine $(P=0.017)$.

Mean conjunctival redness scores were also lower for all alcaftadine treatment groups and the olopatadine treatment group compared with placebo at each time point. The alcaftadine $0.25 \%$ and olopatadine treatment groups had statistically significantly lower mean scores at all postchallenge time points (Figure 2, Table 3). Moreover, only alcaftadine $0.25 \%$ produced mean scores that were clinically significantly lower than those of the placebo group: 1.00 and 1.01 unit differences at 7 and 15 minutes post-CAC, respectively (Figure 2, Table 3).

\section{Secondary endpoints}

At both the 15-minute and 16-hour postinstillation evaluations, both the alcaftadine $0.25 \%$ and olopatadine treatment groups exhibited statistically significantly lower mean scores than placebo for all secondary endpoints (ocular itching and conjunctival redness at all nonprimary endpoints, ciliary and episcleral redness, chemosis, lid swelling, tearing, ocular mucous discharge, and nasal symptoms) at every time point $(P<0.05)$. Ocular mucous discharge was noted only in one subject treated with alcaftadine $0.25 \%$ at 7 minutes after a challenge at the duration of action evaluation (visit 3 ). 
Table 2 Ocular itching scores compared with placebo

\begin{tabular}{|c|c|c|c|c|c|c|c|c|c|}
\hline \multirow{2}{*}{$\begin{array}{l}\text { Time point } \\
\text { post-CAC }\end{array}$} & \multirow{2}{*}{$\begin{array}{l}\text { Placebo } \\
\text { Mean } \\
\text { score }\end{array}$} & \multicolumn{2}{|c|}{ Alcaftadine $0.05 \%$} & \multicolumn{2}{|c|}{ Alcaftadine $0.1 \%$} & \multicolumn{2}{|c|}{ Alcaftadine $0.25 \%$} & \multicolumn{2}{|c|}{ Olopatadine $0.1 \%$} \\
\hline & & $\begin{array}{l}\text { Mean } \\
\text { score }\end{array}$ & $\begin{array}{l}\text { Mean } \\
\text { difference } \\
\text { vs placebo }\end{array}$ & $\begin{array}{l}\text { Mean } \\
\text { score }\end{array}$ & $\begin{array}{l}\text { Mean } \\
\text { difference } \\
\text { vs placebo }\end{array}$ & $\begin{array}{l}\text { Mean } \\
\text { score }\end{array}$ & $\begin{array}{l}\text { Mean } \\
\text { difference } \\
\text { vs placebo }\end{array}$ & $\begin{array}{l}\text { Mean } \\
\text { score }\end{array}$ & $\begin{array}{l}\text { Mean } \\
\text { difference } \\
\text { vs placebo }\end{array}$ \\
\hline $\begin{array}{l}\text { I5-minute onset of action } \\
\text { challenge (visit } 4 \text { ) }\end{array}$ & $\mathrm{n}=33$ & \multicolumn{2}{|c|}{$\mathrm{n}=33^{*}$} & \multicolumn{2}{|c|}{$\mathrm{n}=33$} & \multicolumn{2}{|c|}{$\mathrm{n}=32$} & \multicolumn{2}{|c|}{$n=33$} \\
\hline $3 \min$ & 2.22 & 0.53 & $-1.69^{\mathrm{a}, \mathrm{b}}$ & 0.56 & $-1.66^{\mathrm{a}, \mathrm{b}}$ & 0.27 & $-1.95^{\mathrm{a}, \mathrm{b}}$ & 0.33 & $-1.89^{a, b}$ \\
\hline $5 \mathrm{~min}$ & 2.33 & 0.72 & $-\left.1.6\right|^{\mathrm{a}, \mathrm{b}}$ & 0.60 & $-1.73^{\mathrm{a}, \mathrm{b}}$ & 0.41 & $-1.92^{\mathrm{a}, \mathrm{b}}$ & 0.49 & $-1.84^{\mathrm{a}, \mathrm{b}}$ \\
\hline $7 \mathrm{~min}$ & 2.14 & 0.69 & $-1.45^{\mathrm{a}, \mathrm{b}}$ & 0.55 & $-1.59^{\mathrm{a}, \mathrm{b}}$ & 0.37 & $-1.77^{\mathrm{a}, \mathrm{b}}$ & 0.48 & $-1.66^{\mathrm{a}, \mathrm{b}}$ \\
\hline $\begin{array}{l}\text { 16-hour duration of action } \\
\text { challenge (visit 3) }\end{array}$ & $\mathrm{n}=34$ & \multicolumn{2}{|c|}{$\mathrm{n}=34$} & \multicolumn{2}{|c|}{$\mathrm{n}=34$} & \multicolumn{2}{|c|}{$\mathrm{n}=34$} & \multicolumn{2}{|c|}{$\mathrm{n}=34$} \\
\hline $3 \min$ & 1.75 & 0.40 & $-1.35^{\mathrm{a}, \mathrm{b}}$ & 0.31 & $-1.44^{\mathrm{a}, \mathrm{b}}$ & 0.27 & $-1.48^{\mathrm{a}, \mathrm{b}}$ & 0.63 & $-1.12^{\mathrm{a}, \mathrm{b}}$ \\
\hline $5 \mathrm{~min}$ & 1.88 & 0.52 & $-1.35^{\mathrm{a}, \mathrm{b}}$ & 0.47 & $-1.40^{\mathrm{a}, \mathrm{b}}$ & 0.40 & $-1.47^{\mathrm{a}, \mathrm{b}}$ & 0.79 & $-1.08^{\mathrm{a}, \mathrm{b}}$ \\
\hline $7 \mathrm{~min}$ & 1.83 & 0.56 & $-1.27^{\mathrm{a}, \mathrm{b}}$ & 0.48 & $-1.35^{\mathrm{a}, \mathrm{b}}$ & 0.43 & $-1.40^{\mathrm{a}, \mathrm{b}}$ & 0.85 & $-0.99^{a}$ \\
\hline
\end{tabular}

Notes: aSignificant mean difference from placebo $(P<0.05)$; ${ }^{b}$ Clinically significant $\left(\geq 1\right.$ unit) difference from placebo; ${ }^{*} n=32$ at $7-$ minute time point.

Treatment with alcaftadine $0.25 \%$ consistently resulted in lower or equivalent scores than treatment with olopatadine.

\section{Adverse events}

The incidence of adverse events, including ocular adverse events or any adverse events related to the study medication, did not increase with increasing concentrations of alcaftadine. Only one subject (receiving alcaftadine $0.25 \%$ ) had a serious adverse event (dyspnea), which was unrelated to the study drug and caused early withdrawal from the study.

The ocular adverse events are listed in Table 4. All of these were self-limiting, resolved without treatment, and were graded as mild or moderate by the investigators. There were no ocular adverse events in the olopatadine group.

The most common nonocular adverse event was nasopharyngitis, reported in a total of six subjects (3.5\%): one each in the placebo and alcaftadine $0.25 \%$ groups, and two each in

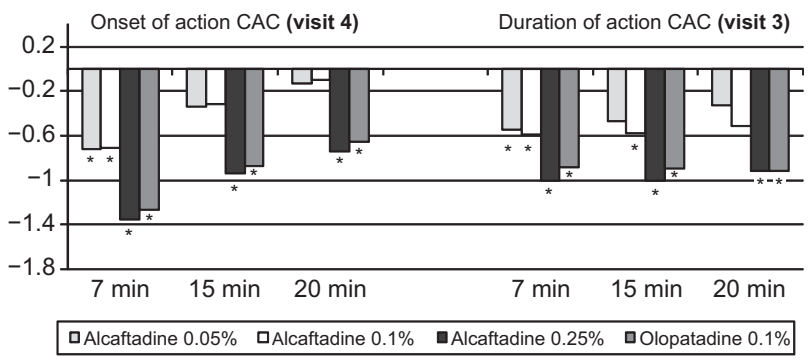

Figure 2 Conjunctival redness scores at 7, 15, and 20 minutes postchallenge. Plots show the mean difference (treatment score - placebo score) for each group. Note: *Statistically significant difference from placebo $(P<0.05)$. On the left, data for onset of action, CAC 15 minutes after instillation. On the right, data for duration of action, CAC 16 hours after instillation.

Abbreviation: CAC, conjunctival allergen challenge. the alcaftadine $0.05 \%$ and olopatadine groups. Dysgeusia, headache, and pharyngolaryngeal pain were reported in two subjects; otitis media, urinary tract infection, muscle spasms, dyspnea, nasal congestion, pruritus, rash, and skin irritation were each reported in one subject. In addition, no clinically significant changes were noted in visual acuity, ophthalmic examinations, or undilated funduscopy.

\section{Discussion}

The CAC model is a well established method used to evaluate the efficacy of antiallergic medication. ${ }^{8}$ It was the pivotal study design used in the approval of all commercially marketed eye drops in the antihistamine-mast cell stabilizer drug class. The screening process during a CAC study ensures that all enrolled subjects demonstrate a reproducible moderate-to-severe allergic reaction. The primary efficacy variables generally assessed in CAC studies are ocular itching and conjunctival redness, the hallmark symptom and sign, respectively, of ocular allergy.

The active control used in this study was olopatadine hydrochloride ophthalmic solution $0.1 \%$ (Patanol ${ }^{\circledR}$, Alcon Laboratories Inc). Olopatadine is the first dual-function antiallergic agent approved by the Food and Drug Administration (FDA) for the treatment of the signs and symptoms of allergic conjunctivitis. The recommended dose for olopatadine hydrochloride ophthalmic solution $0.1 \%$ is one drop two times per day at an interval of six to eight hours. ${ }^{9}$ Although not available at the time of the study, olopatadine $0.2 \%$ is indicated for itching alone and recommended for once-daily dosing. In comparison with olopatadine, the other dual-function (antihistamine, mast cell stabilizers) topical ophthalmic solutions (ketotifen fumarate $0.025 \%$, azelastine hydrochloride 
Table 3 Conjunctival redness scores compared with placebo

\begin{tabular}{|c|c|c|c|c|c|c|c|c|c|}
\hline \multirow{2}{*}{$\begin{array}{l}\text { Time point } \\
\text { post-CAC }\end{array}$} & \multirow{2}{*}{$\begin{array}{l}\text { Placebo } \\
\text { Mean } \\
\text { score }\end{array}$} & \multicolumn{2}{|c|}{ Alcaftadine $0.05 \%$} & \multicolumn{2}{|c|}{ Alcaftadine $0.1 \%$} & \multicolumn{2}{|c|}{ Alcaftadine $0.25 \%$} & \multicolumn{2}{|c|}{ Olopatadine $0.1 \%$} \\
\hline & & $\begin{array}{l}\text { Mean } \\
\text { score }\end{array}$ & $\begin{array}{l}\text { Mean } \\
\text { difference } \\
\text { vs placebo }\end{array}$ & $\begin{array}{l}\text { Mean } \\
\text { score }\end{array}$ & $\begin{array}{l}\text { Mean } \\
\text { difference } \\
\text { vs placebo }\end{array}$ & $\begin{array}{l}\text { Mean } \\
\text { score }\end{array}$ & $\begin{array}{l}\text { Mean } \\
\text { difference } \\
\text { vs placebo }\end{array}$ & $\begin{array}{l}\text { Mean } \\
\text { score }\end{array}$ & $\begin{array}{l}\text { Mean } \\
\text { difference } \\
\text { vs placebo }\end{array}$ \\
\hline $\begin{array}{l}\text { I5-minute onset of action } \\
\text { challenge (visit 4) }\end{array}$ & $\mathrm{n}=33$ & \multicolumn{2}{|c|}{$\mathrm{n}=33$} & \multicolumn{2}{|c|}{$n=33$} & \multicolumn{2}{|c|}{$\mathrm{n}=32$} & \multicolumn{2}{|c|}{$n=33$} \\
\hline $7 \mathrm{~min}$ & 1.85 & 1.13 & $-0.72^{\mathrm{a}}$ & $\mathrm{I} .14$ & $-0.70^{\mathrm{a}}$ & 0.50 & $-1.35^{\mathrm{a}, \mathrm{b}}$ & 0.58 & $-1.27^{\mathrm{a}, \mathrm{b}}$ \\
\hline $15 \mathrm{~min}$ & 1.96 & 1.62 & -0.34 & 1.64 & -0.32 & $1.02^{\mathrm{a}}$ & -0.94 & 1.09 & $-0.87^{a}$ \\
\hline $20 \mathrm{~min}$ & 1.80 & 1.67 & -0.12 & 1.70 & -0.10 & $1.06^{\mathrm{a}}$ & -0.73 & 1.15 & $-0.64^{\mathrm{a}}$ \\
\hline $\begin{array}{l}\text { 16-hour duration of action } \\
\text { challenge (visit 3) }\end{array}$ & $\mathrm{n}=34$ & \multicolumn{2}{|c|}{$\mathrm{n}=34$} & \multicolumn{2}{|c|}{$\mathrm{n}=34$} & \multicolumn{2}{|c|}{$n=34$} & \multicolumn{2}{|c|}{$\mathrm{n}=34$} \\
\hline $7 \mathrm{~min}$ & $\mathrm{I} .77$ & 1.22 & $-0.55^{\mathrm{a}}$ & 1.18 & $-0.59^{a}$ & 0.77 & $-1.0^{\mathrm{a}, \mathrm{b}}$ & 0.89 & $-0.88^{a}$ \\
\hline $15 \mathrm{~min}$ & 2.02 & 1.55 & -0.47 & 1.44 & $-0.58^{a}$ & 1.01 & $-|.0|^{\mathrm{a}, \mathrm{b}}$ & 1.12 & $-0.9^{a}$ \\
\hline $20 \mathrm{~min}$ & 1.91 & 1.58 & -0.33 & 1.40 & -0.51 & 0.99 & $-0.93^{a}$ & 0.99 & $-0.93^{a}$ \\
\hline
\end{tabular}

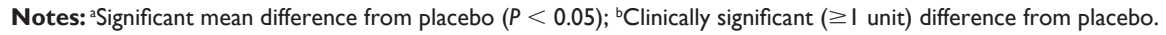

$0.05 \%$, epinastine hydrochloride $0.05 \%$ ) are indicated for the prevention of ocular itching only and recommended for twice-daily dosing.

The data presented in this report indicate that of all three alcaftadine ophthalmic solutions tested, alcaftadine $0.25 \%$ ophthalmic solution performed most effectively in preventing the signs and symptoms of allergic conjunctivitis. Alcaftadine $0.25 \%$ was effective in reducing both ocular itching and conjunctival redness at the onset of action and duration of action evaluations (CAC at 15 minutes and 16 hours following

Table 4 Incidence of ocular adverse events

\begin{tabular}{|c|c|c|c|c|c|c|}
\hline \multirow{2}{*}{$\begin{array}{l}\text { System organ class/ } \\
\text { preferred term }^{\text {a }}\end{array}$} & \multirow{2}{*}{$\begin{array}{l}\text { Placebo } \\
(n=34)^{a} \\
n(\%)\end{array}$} & \multicolumn{3}{|c|}{ Alcaftadine } & \multirow{2}{*}{$\begin{array}{l}\text { Olopatadine } \\
0.1 \% \\
(n=34)^{a} \\
n(\%)\end{array}$} & \multirow{2}{*}{$\begin{array}{l}\text { Total } \\
(\mathbf{N}=\mid \mathbf{7 0})^{\mathrm{a}} \\
\mathrm{n}(\%)\end{array}$} \\
\hline & & $\begin{array}{l}0.05 \% \\
(n=34)^{a} \\
n(\%)\end{array}$ & $\begin{array}{l}0.10 \% \\
(n=34)^{a} \\
n(\%)\end{array}$ & $\begin{array}{l}0.25 \% \\
(n=34)^{a} \\
n(\%)\end{array}$ & & \\
\hline \multicolumn{7}{|l|}{ Ocular - right eye } \\
\hline \multicolumn{7}{|l|}{ Eye disorders } \\
\hline Abnormal sensation in eye & $0(0.0)$ & $0(0.0)$ & $0(0.0)$ & I (2.9) & $0(0.0)$ & $\mathrm{I}(0.6)$ \\
\hline Asthenopia & I (2.9) & $0(0.0)$ & $0(0.0)$ & I (2.9) & $0(0.0)$ & $2(1.2)$ \\
\hline Photophobia & $0(0.0)$ & $0(0.0)$ & $0(0.0)$ & I (2.9) & $0(0.0)$ & I $(0.6)$ \\
\hline Visual acuity reduced & $0(0.0)$ & I (2.9) & $0(0.0)$ & $0(0.0)$ & $0(0.0)$ & $\mathrm{I}(0.6)$ \\
\hline Total $^{b}$ & I (2.9) & I (2.9) & $0(0.0)$ & $3(8.8)$ & $0(0.0)$ & $5(2.9)$ \\
\hline \multicolumn{7}{|c|}{ General disorders and administration site conditions } \\
\hline Application site dryness & I (2.9) & I (2.9) & $0(0.0)$ & $0(0.0)$ & $0(0.0)$ & $2(1.2)$ \\
\hline Application site paresthesia & I (2.9) & $0(0.0)$ & $0(0.0)$ & $0(0.0)$ & $0(0.0)$ & I $(0.6)$ \\
\hline Application site pruritus & $2(5.9)$ & I (2.9) & $0(0.0)$ & I (2.9) & $0(0.0)$ & $4(2.4)$ \\
\hline Instillation site stinging & $0(0.0)$ & $4(11.8)$ & $3(8.8)$ & $2(5.9)$ & $0(0.0)$ & $9(5.3)$ \\
\hline Sensation of pressure & $0(0.0)$ & $0(0.0)$ & $0(0.0)$ & I (2.9) & $0(0.0)$ & I $(0.6)$ \\
\hline Total & $2(5.9)$ & $6(17.6)$ & $3(8.8)$ & $4(I I .8)$ & $0(0.0)$ & $15(8.8)$ \\
\hline \multicolumn{7}{|l|}{ Ocular - left eye } \\
\hline \multicolumn{7}{|l|}{ Eye disorders } \\
\hline Abnormal sensation in eye & $0(0.0)$ & $0(0.0)$ & $0(0.0)$ & I (2.9) & $0(0.0)$ & $\mathrm{I}(0.6)$ \\
\hline Asthenopia & I (2.9) & $0(0.0)$ & $0(0.0)$ & I (2.9) & $0(0.0)$ & $2(1.2)$ \\
\hline Photophobia & $0(0.0)$ & $0(0.0)$ & $0(0.0)$ & I (2.9) & $0(0.0)$ & $\mathrm{I}(0.6)$ \\
\hline Total $^{\mathrm{b}}$ & I (2.9) & $0(0.0)$ & $0(0.0)$ & $3(8.8)$ & $0(0.0)$ & $4(2.4)$ \\
\hline \multicolumn{7}{|c|}{ General disorders and administration site conditions } \\
\hline Application site dryness & I (2.9) & I (2.9) & $0(0.0)$ & $0(0.0)$ & $0(0.0)$ & $2(1.2)$ \\
\hline Application site paresthesia & I (2.9) & $0(0.0)$ & $0(0.0)$ & $0(0.0)$ & $0(0.0)$ & $\mathrm{I}(0.6)$ \\
\hline Application site pruritus & $2(5.9)$ & I (2.9) & $0(0.0)$ & $\mathrm{I}(2.9)$ & $0(0.0)$ & $4(2.4)$ \\
\hline Instillation site stinging & $0(0.0)$ & $3(8.8)$ & $3(8.8)$ & $2(5.9)$ & $0(0.0)$ & $8(4.7)$ \\
\hline Sensation of pressure & $0(0.0)$ & $0(0.0)$ & $0(0.0)$ & I (2.9) & $0(0.0)$ & I $(0.6)$ \\
\hline Total & $2(5.9)$ & $5(14.7)$ & $3(8.8)$ & $4(I I .8)$ & $0(0.0)$ & $14(8.2)$ \\
\hline
\end{tabular}

Notes: a MedDRA dictionary (version 7.0 ) is used for coding; ${ }^{\circ}$ Total includes subjects only once even if they had more than one adverse event in a body system or overall. 
administration of study medication, respectively). The onset of action data at visit 4 for alcaftadine $0.25 \%$ are superior to those for olopatadine $0.1 \%$. Statistically significant results were observed for the prevention of signs and symptoms in both alcaftadine $0.25 \%$ and olopatadine $0.1 \%$ treatment groups when compared with placebo at the majority of onset and duration assessments.

The efficacy of alcaftadine $0.25 \%$ ophthalmic solution also appears to demonstrate persistency; only a $24 \%$ reduction in the mean difference from placebo in three-minute post-CAC itching was observed for alcaftadine $0.25 \%$ (1.95 and 1.48 unit differences from placebo) between onset and duration assessments. These data also show that the effectiveness of alcaftadine $0.25 \%$ detected at the 15 -minute postdose CAC evaluation persists for at least 16 hours after instillation, raising the possibility for a once-daily recommended dose administration regimen. Furthermore, the robust efficacy of alcaftadine $0.25 \%$ in preventing the signs and symptoms of allergic conjunctivitis 16 hours after a single dose may suggest a lasting protective mechanism. Although clinical research is required to confirm the preclinical zonula occludin-1stabilization in humans, this confirmation may substantiate the mechanism behind the long-lasting protection observed in the current study.

In conclusion, alcaftadine $0.25 \%$ ophthalmic solution was effective, showing superiority over placebo in preventing both the symptom of ocular itching and the sign of conjunctival redness of the CAC-induced allergic response. This effectiveness was demonstrated at 15 minutes and 16 hours after instillation, indicating that alcaftadine $0.25 \%$ has a rapid onset of action and a substantial duration of action, making it a candidate for once-daily dosing for the prevention of itching due to allergic conjunctivitis. In July 2010, alcaftadine
$0.25 \%$ ophthalmic solution received FDA approval for the prevention of itching in the US.

\section{Acknowledgment}

The authors thank Ratna Ramaswamy for statistical design and oversight of its execution.

\section{Disclosure}

This study was supported by Vistakon Pharmaceuticals, LLC. Johnson \& Johnson Vision Care is the parent of Vistakon Pharmaceuticals, LLC.

\section{References}

1. Abelson MB, Smith L, Chapin M. Ocular allergic disease: Mechanisms, disease sub-types, treatment. Ocul Surf. 2003;1(3):38-60.

2. Abelson MB, Loffler O. Conjunctival allergen challenge: Models in the investigation of ocular allergy. Curr Allergy Asthma Rep. 2003;3(4):363-368.

3. Church MK, McGill JI. Human ocular mast cells. Curr Opin Allergy Clin Immunol. 2002;2(5):419-422.

4. Abelson MB, Udell IJ. $\mathrm{H}_{2}$-receptors in the human ocular surface. Arch Ophthalmol. 1981;99(2):302-304.

5. Nakano Y, Takahashi Y, Ono R, et al. Role of histamine $\mathrm{H}_{4}$ receptor in allergic conjunctivitis in mice. Eur $J$ Pharmacol. 2009;608(1-3):71-75.

6. Thurmond RL, Gelfand EW, Dunford PJ. The role of histamine $\mathrm{H}_{1}$ and $\mathrm{H}_{4}$ receptors in allergic inflammation: The search for new antihistamines. Nat Rev Drug Discov. 2008;7(1):41-53.

7. Zampeli E, Thurmond RL, Tiligada E. The histamine $\mathrm{H}_{4}$ receptor antagonist JNJ7777120 induces increases in the histamine content of the rat conjunctiva. Inflamm Res. 2009;58(6):285-291.

8. Abelson MB, Chambers WA, Smith LM. Conjunctival allergen challenge. A clinical approach to studying allergic conjunctivitis. Arch Ophthalmol. 1990;108(1):84-88.

9. Patanol ${ }^{\circledR}$ [Prescribing information]. Fort Worth, TX: Alcon Laboratories, Inc; 2007.

10. Abelson MB, Sangler DL, Epstein AB, et al. Efficacy of once-daily olopatadine $0.2 \%$ ophthalmic solution compared to twice-daily olopatadine $0.1 \%$ ophthalmic solution for the treatment of ocular itching induced by conjunctival allergen challenge. Curr Eye Res. 2007;32(12):1017-1022.
Clinical Ophthalmology

\section{Publish your work in this journal}

Clinical Ophthalmology is an international, peer-reviewed journal covering all subspecialties within ophthalmology. Key topics include: Optometry; Visual science; Pharmacology and drug therapy in eye diseases; Basic Sciences; Primary and Secondary eye care; Patient Safety and Quality of Care Improvements. This journal is indexed on

\section{Dovepress}

PubMed Central and CAS, and is the official journal of The Society of Clinical Ophthalmology (SCO). The manuscript management system is completely online and includes a very quick and fair peer-review system, which is all easy to use. Visit http://www.dovepress.com/ testimonials.php to read real quotes from published authors. 